Electronic Supplementary Information

\title{
Understanding Mechanochromic Luminescence on Account of Molecular Level Based on Phosphorescent Iridium(III) Complex Isomers
}

Guangfu Li, ${ }^{\dagger}$ Tianzhi Yang, ${ }^{\dagger}$ Kuizhan Shao, ${ }^{\dagger}$ Ying Gao, ${ }^{\ddagger}$ Guogang Shan,,${ }^{*}{ }^{\dagger}$ Zhongmin Su, ${ }^{\dagger}$ Xinlong Wang, ${ }^{*}{ }^{\dagger}$ and Dongxia Zhu*,†

${ }^{a}$ Key Laboratory of Nanobiosensing and Nanobioanalysis at Universities of Jilin Province, Department of Chemistry, North-east Normal University, 5268 Renmin Street, Changchun, Jilin Province 130024, P. R. China; Fax: +86-0431-85684009

Tel.:+86-431-85099108,E-mail: shangg187@nenu.edu.cn; zhudx047@nenu.edu.cn;wangxl824@nenu.edu.cn

${ }^{b}$ Institute for Interdisciplinary Biomass Functional Materials Studies, Jilin Engineering Normal University,

Changchun 130052, P. R. China

\section{Table of Contents}

1. Reference Samples

2. ${ }^{13} \mathrm{C}$ NMR Spectra

3. Photophysical Properties

4. TEM and ED Experiments

5. TGA and DSC Curves

6. X-ray Crystallographic Data

7. TD-DFT Calculations 


\section{Reference Samples}

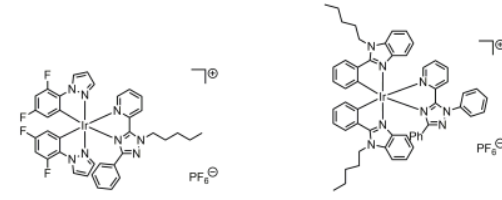

ref.19 MLCTRLCT

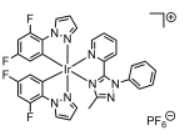

ref. 24 MLCT/LLCT

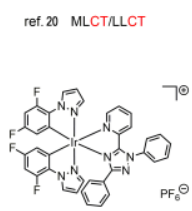

ref. 25 MLCT/LLCT

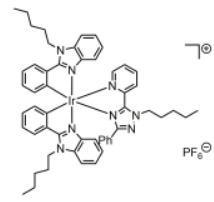

ref.21 MLCT/LLCT

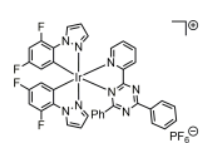

ref. 26 MLCT/LLCT

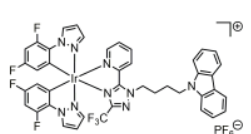

ref. 22 ILCT

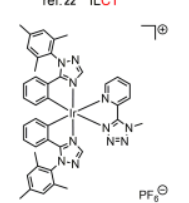

ref 27 MLCTLLCT

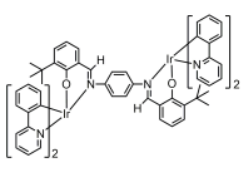

ref. 32 MLCT/LLCT

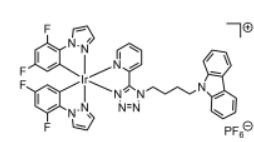

ref.23 ILCT

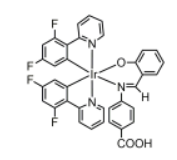

ref. 28 MLCT/LLCT
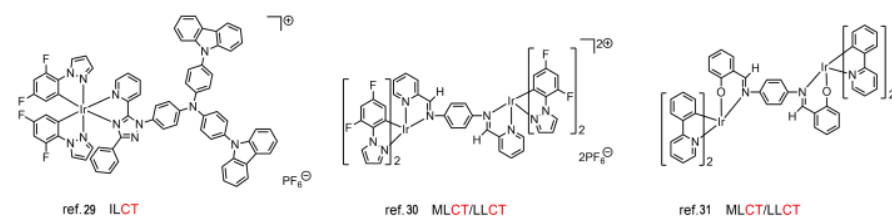

ref.31 MLCT/LLCT

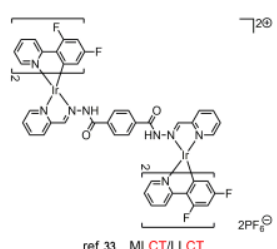

Figure S1. The representative MCL-active iridium(III) complexes previously reported.

\section{2. ${ }^{13}$ C NMR Spectra}
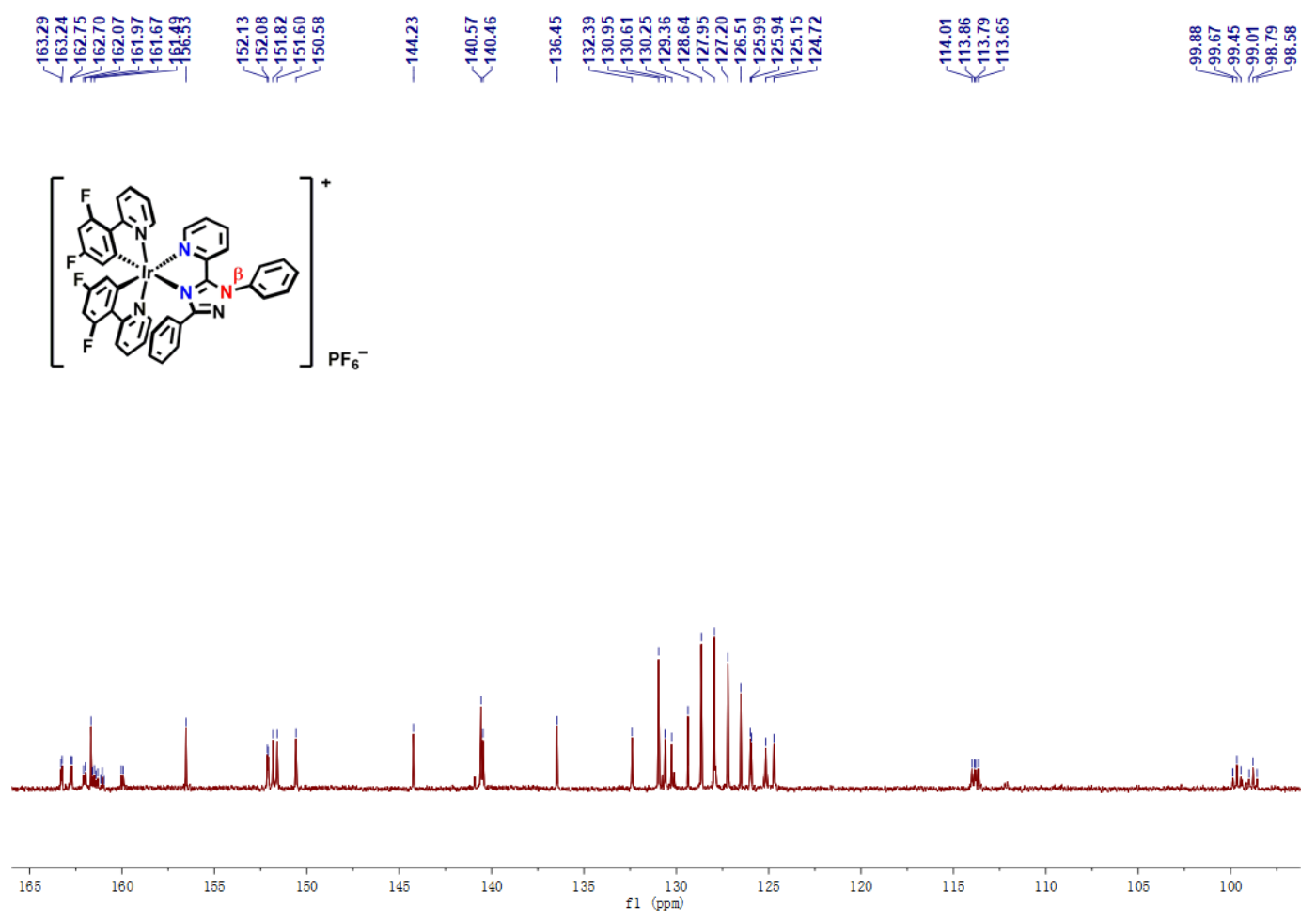

Figure S2. The ${ }^{13} \mathrm{C}$ NMR spectrum of complex 1 in DMSO- $d_{6}$. 

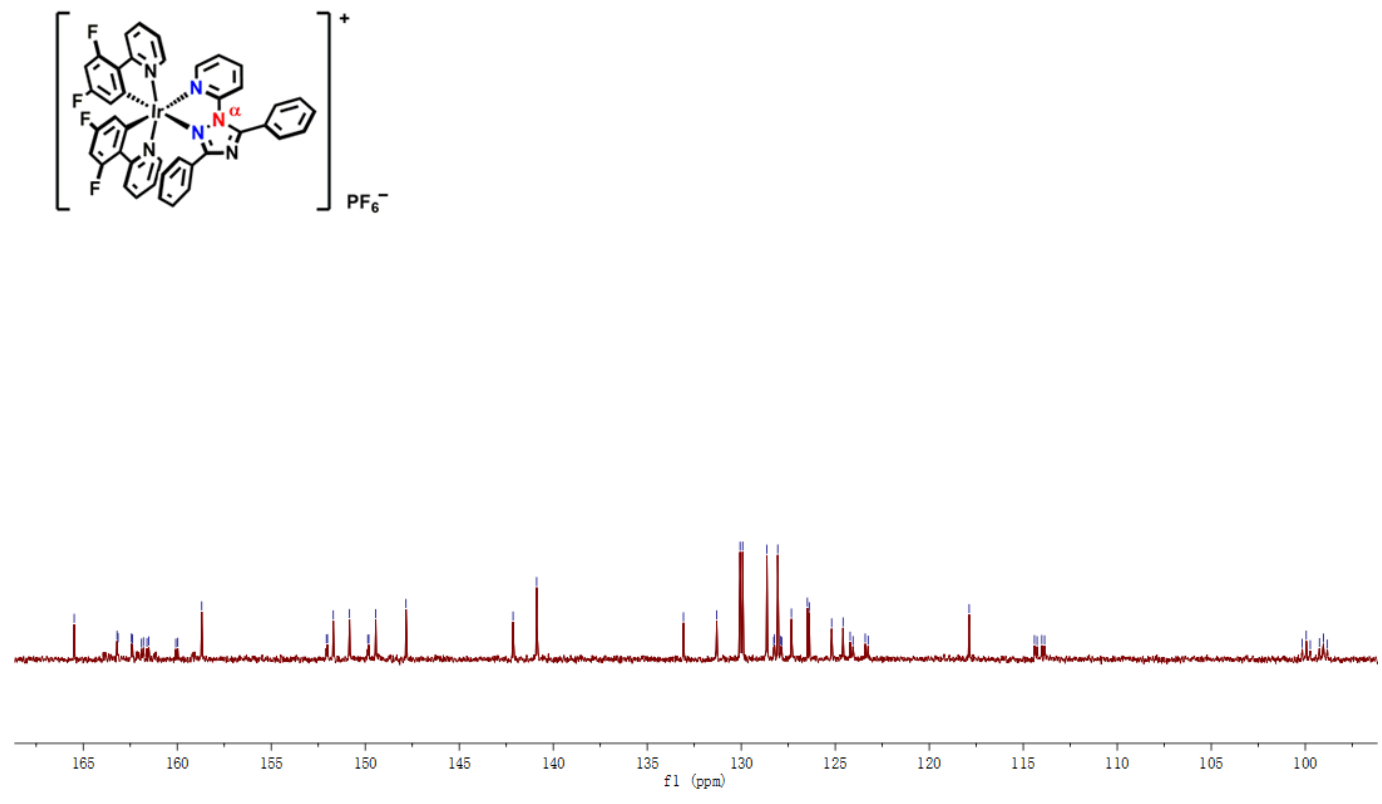

Figure S3. The ${ }^{13} \mathrm{C}$ NMR spectrum of complex 2 in DMSO- $d 6$.

\section{Photophysical Properties}

(a)

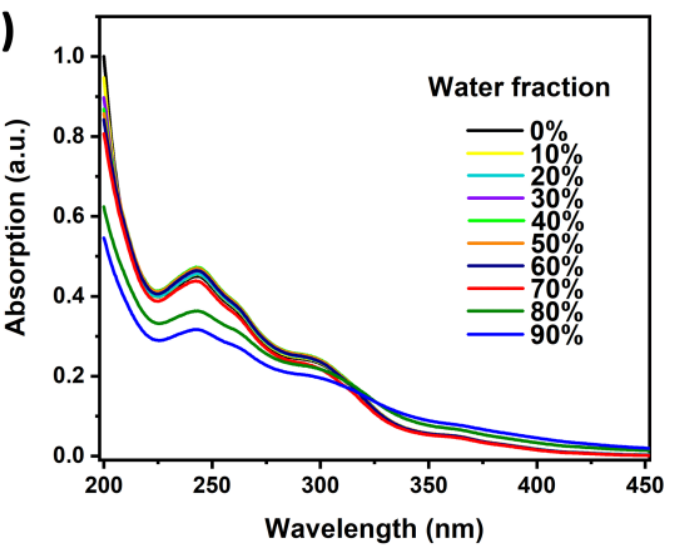

(b)

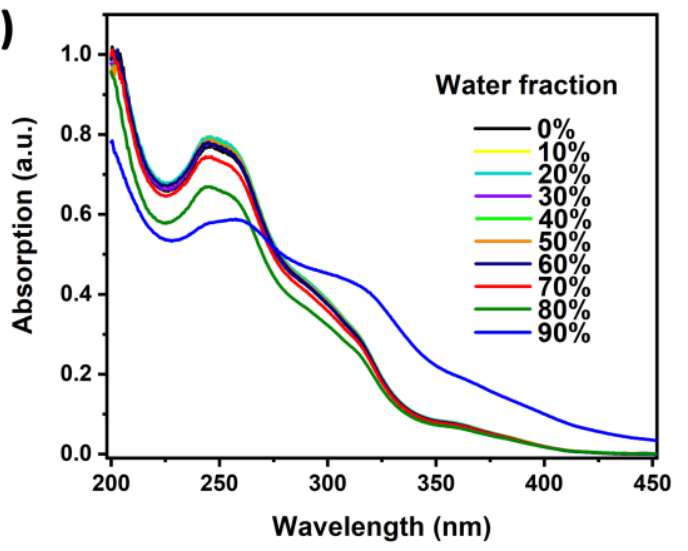

Figure S4. UV-Vis absorption spectra of isomers 1 (a) and 2 (b) in $\mathrm{CH}_{3} \mathrm{CN}-\mathrm{H}_{2} \mathrm{O}$ mixtures with different water fractions (0-90\%). 


\section{TEM and ED Experiments}
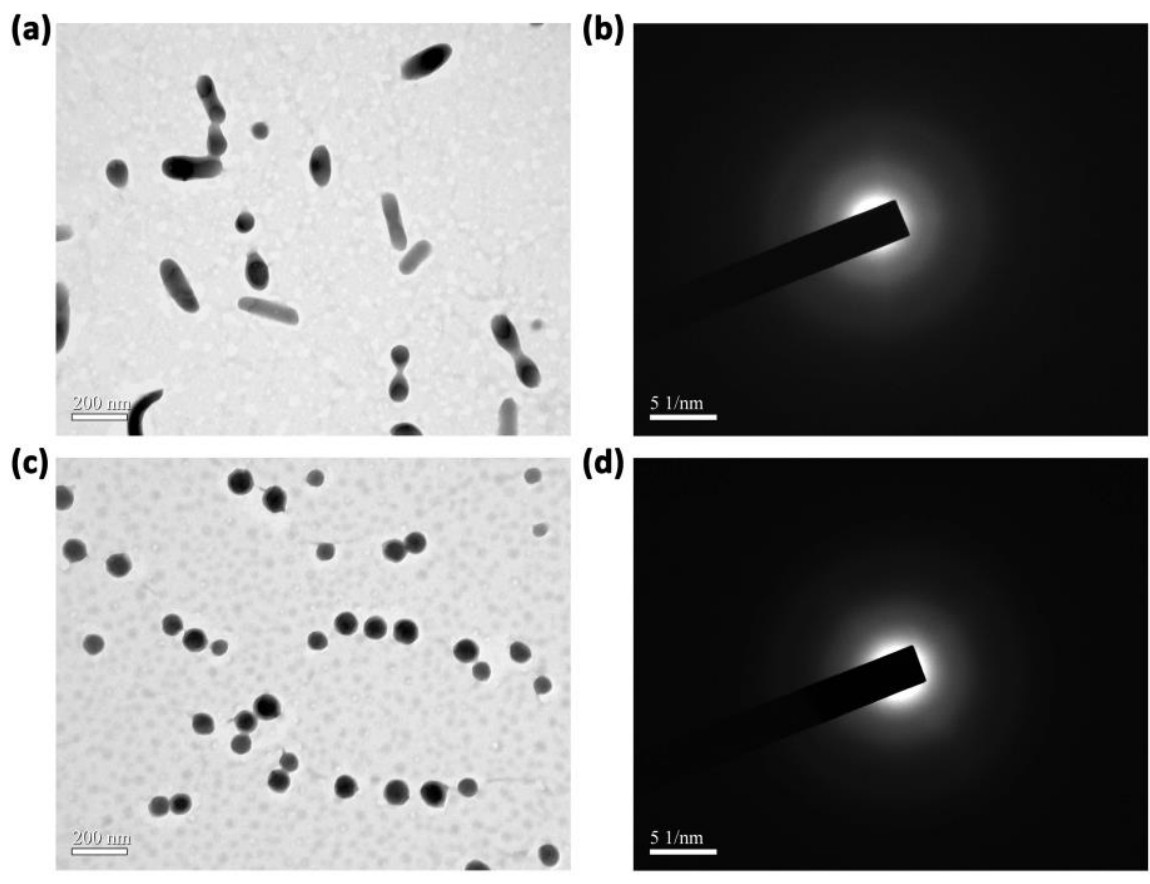

Figure S5. TEM images of nanoaggregates of isomers 1 (a) and 2 (c) formed in $\mathrm{CH}_{3} \mathrm{CN}-\mathrm{H}_{2} \mathrm{O}$ mixtures with $90 \%$ water fraction. And corresponding electron diffraction pattern of the nanoaggregates of isomers 1 (b) and 2 (d).

\section{TGA and DSC Curves}
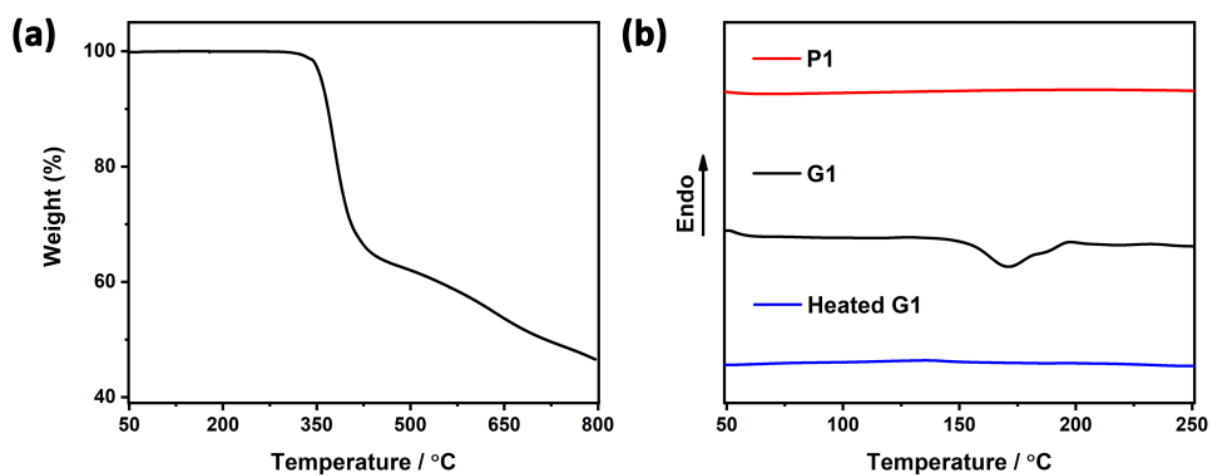

Figure S6. (a) TGA curve of P1. (b) DSC curves of P1, G1 and Heated G1. 


\section{X-ray crystallographic data}

The molecular structures of iridium(III) complex isomers $\mathbf{1}$ and $\mathbf{2}$ were confirmed by X-ray crystallographic analysis of single crystals. The crystals for both isomers were obtained by the solvent diffusion method (from n-pentane to dichloromethane). Diffraction data were collected on a Bruker SMART Apex CCD diffractometer using $\mathrm{k}(\mathrm{Mo}-\mathrm{K})$ radiation $(\mathrm{k}=0.71069 \AA)$. Cell refinement and data reduction were made by the SAINT program. The structure was determined using the SHELXTL/PC program. The crystallographic data have been deposited with the Cambridge Crystallographic Data Centre with CCDC deposition numbers 2002958 (isomer 1) and 2002959 (isomer 2). These data can be obtained free of charge from The Cambridge Crystallographic Data Centre via www.ccdc.cam.ac.uk/data_request/cif.

Table S1. Crystal Data and Structure Refinement for Isomers $\mathbf{1}$ and $\mathbf{2}$

\begin{tabular}{lll}
\hline & isomer 1 & isomer 2 \\
\hline Empirical formula & \multicolumn{1}{c}{$\mathrm{C}_{41} \mathrm{H}_{26} \mathrm{~F}_{4} \mathrm{IrN}_{6} \cdot \mathrm{PF}_{6} \cdot \mathrm{CH}_{2} \mathrm{Cl}_{2}$} & \multicolumn{1}{c}{$\mathrm{C}_{41} \mathrm{H}_{26} \mathrm{~F}_{4} \mathrm{IrN}_{6} \cdot \mathrm{PF}_{6} \cdot \mathrm{CH}_{2} \mathrm{Cl}_{2}$} \\
Formula weight & 1100.77 & 1100.77 \\
Temperature $(\mathrm{K})$ & 293 & 173 \\
Crystal system & Triclinic & Triclinic \\
space group & $\mathrm{P}-1$ & $\mathrm{P}-1$ \\
$\mathrm{a} / \AA$ & $9.238(5)$ & $9.0411(7)$ \\
$\mathrm{b} / \AA$ & $13.659(5)$ & $13.7317(10)$ \\
$\mathrm{c} / \AA$ & $17.037(5)$ & $16.8868(12)$ \\
$\alpha /{ }^{\circ}$ & $81.925(5)$ & $82.003(3)$ \\
$\beta /{ }^{\circ}$ & $80.063(5)$ & $80.642(3)$ \\
$\gamma /{ }^{\circ}$ & $84.616(5)$ & $84.524(3)$ \\
$\mathrm{V} / \AA^{3}$ & $2091.2(15)$ & $2042.8(3)$ \\
$\mathrm{Z}$ & 2 & 2 \\
$\rho_{\text {calc }}\left(\mathrm{g} / \mathrm{cm}{ }^{3}\right)$ & 1.748 & 1.790 \\
$\mu / \mathrm{mm}^{-1}$ & 3.443 & 8.672 \\
\hline
\end{tabular}




\begin{tabular}{|c|c|c|}
\hline $\mathrm{R}_{\text {int }}$ & 0.0777 & 0.0472 \\
\hline $\begin{array}{l}\text { Goodness-of-fit } \\
\text { on } \mathrm{F}^{2}\end{array}$ & 1.092 & 1.074 \\
\hline $\begin{array}{l}\mathrm{R}_{1}^{\mathrm{a}} \\
\mathrm{wR}_{2}{ }^{\mathrm{b}}[\mathrm{I}>2 \sigma(\mathrm{I})]\end{array}$ & $0.0373,0.0843$ & $0.0321,0.0807$ \\
\hline $\mathrm{R}_{1}, \mathrm{wR}_{2}$ (all data) & $0.0528,0.0911$ & $0.0340,0.0828$ \\
\hline
\end{tabular}

\section{TD-DFT Calculations}

The calculations reported here were carried out by using the Gaussian 09 software package. ${ }^{1}$ The geometrical structures of the ground state and the lowest triplet state for iridium(III) complexes were fully optimized with C1 symmetry constraints by using the restricted closed-shell and openshell B3LYP methods with the LANL2DZ basis set for the Ir atom and $6-31 G^{*}$ for the rest of the atoms. ${ }^{2}$ The effective core potential on Ir replaced the inner-core electrons, leaving the outer core $(5 s) 2(5 p) 6$ electrons and the (5d)6 valence electrons of iridium(III). On the basis of the optimized structures, the time-dependent DFT (TD-DFT) calculations were performed in order to study the excited state property. The solvent effect was also considered with the polarized continuum model.

Table S2. Excited State Transition Components of Isomers 1 and 2 Calculated by TD-DFT Method

\begin{tabular}{lcccccc}
\hline & States & $\mathrm{E}(\mathrm{eV})$ & $f$ & $\begin{array}{c}\text { Transition } \\
\text { dipole moment } \\
\text { (Debye) }\end{array}$ & Assignment ${ }^{a}$ & Nature \\
\hline $\mathbf{1}$ & $\mathrm{T}_{1}$ & 2.19 & 0 & 0.266 & $\mathrm{H} \rightarrow \mathrm{L}(61 \%)$ & ${ }^{3} \mathrm{MLCT} /{ }^{3} \mathrm{LLCT}$ \\
& & & & & $\mathrm{H}-3 \rightarrow \mathrm{L}(17 \%)$ & ${ }^{3} \mathrm{MLCT} /{ }^{3} \mathrm{LLCT} /{ }^{3} \mathrm{LC}$ \\
$\mathbf{2}$ & $\mathrm{T}_{1}$ & 1.89 & 0 & 0.0454 & $\mathrm{H} \rightarrow \mathrm{L}(10 \%)$ & ${ }^{3} \mathrm{MLCT} /{ }^{3} \mathrm{LLCT}$ \\
& & & & $\mathrm{H}-1 \rightarrow \mathrm{L}(71 \%)$ & ${ }^{3} \mathrm{MLCT} /{ }^{3} \mathrm{LC}$ \\
\hline
\end{tabular}


${ }^{a} \mathrm{H}$ and $\mathrm{L}$ represent $\mathrm{HOMO}$ and LUMO, respectively.

(1) Frisch, M. J.; Trucks, G. W.; Schlegel, H. B.; Scuseria, G. E.; Robb, M. A.; Cheeseman, J. R.; Scalmani, G.; Barone, V.; Mennucci, B.; Petersson, G. A.; Nakatsuji, H.; Caricato, M.; Li, X.; Hratchian, H. P.; Izmaylov, A. F.; Bloino, J.; Zheng, G.; Sonnenberg, J. L.; Hada, M.; Ehara, M.; Toyota, K.; Fukuda, R.; Hasegawa, J.; Ishida, M.; Nakajima, T.; Honda, Y.; Kitao, O.; Nakai, H.; Vreven, T.; Montgomery, J. A, Jr.; Peralta, J. E.; Ogliaro, F.; Bearpark, M.; Heyd, J. J.; Brothers, E.; Kudin, K. N.; Staroverov, V. N.; Keith, T.; Kobayashi, R.; Normand, J.; Raghavachari, K.; Rendell, A.; Burant, J. C.; Iyengar, S. S.; Tomasi, J.; Cossi, M.; Rega, N.; Millam, J. M.; Klene, M.; Knox, J. E.; Cross, J. B.; Bakken, V.; Adamo, C.; Jaramillo, J.; Gomperts, R.; Stratmann, R. E.; Yazyev, O.; Austin, A. J.; Cammi, R.; Pomelli, C.; Ochterski, J. W.; Martin, R. L.; Morokuma, K.; Zakrzewski, V. G.; Voth, G. A.; Salvador, P.; Dannenberg, J. J.; Dapprich, S.; Daniels, A. D.; Farkas, O.; Foresman, J. B.; Ortiz, J. V.; Cioslowski, J.; Fox, D. J. Gaussian 09, Revision A.01; Gaussian, Inc.: Wallingford, CT, 2009.

(2) Francl, M. M.; Pietro, W. J.; Hehre, W. J.; Binkley, J. S.; Gordon, M. S.; Defrees, D. J.; Pople, J. A. Self-Consistent Molecular Orbital Methods. XXIII. A Polarization-Type Basis Set for Second-row Elements. J. Chem. Phys. 1982, 77, $3654-3665$. 